\title{
Knowledge, attitude and application of computer by Bachelor Level Nursing students
}

Shahi M.

Ph. D Scholar, Singhania University, Rajausthan

Correspondence to: Mrs. Mandira Shahi, National Centre for Health Professions Education, TU, IOM, Maharajgunj, Kathmandu, Nepal

Email : mandiranp@yahoo.com,

\begin{abstract}
Background: Computer literacy and information literacy are critical to the future of nursing in this 21 st century. The objective of the study is to identify the knowledge, attitude and application of computer by the BN 1st year nursing students.

Methods: The study populations were 108 Bachelor of Nursing 1st year nursing students of the three different institutions. The research has adapted descriptive cross-sectional design. In this research study, purposive non- probability convenient sampling technique was adopted to select the nursing institutes. A self-administered structured questionnaire, Likert scale and semi structured questionnaire were used.

Results: The majority of the respondents (44.4\%) were from Central development region. The majority of the respondents $(59.3 \%)$ had taken basic course on computer training. Also, Majority of the respondents $33.3 \%$ respondents had average knowledge on E-mail and Internet. Interestingly, majority (54.9\%) respondents had used computer for medical information occasionally. Similarly, majority of the respondents $(69.7 \%)$ strongly disagreed that 'without computer, world would be better.' Majority of the respondent (37\%) often used Internet/E-mail and chatting in computer. Likewise, the majority of the respondents $(40.7 \%)$ stated that computer is very useful in nursing education and research.
\end{abstract}

Conclusion: The findings of the study indicate that there was a deficit in students' IT competencies should be integrated into the BN 1st year course.

Keywords: Computer, knowledge, skills and attitude

\section{Introduction}

Since the 1950s, people have been trying to use computers, video, and telecommunications to revolutionize education. For decades, their vision was dominated by several ideas about how to use technology to extend the teachers' reach.1

We live in the era of information technology (IT). Many health care organizations have adopted policies favoring the implementation of modern technology. Computers are used not only for diagnosis and imaging techniques but also in home care and long -term facilities. 2

Computers can perform a wide range of activities that save time and help nurses to provide quality nursing care. Nurses need to be aware of the forces having an impact on nursing.
Nurses acquire new roles because of computerization, it is a matter of changing the job profile computerization could resolve certain problems and derive benefits including reduction in clerical work required of professionals, reduction in printed forms, centralized patient care data etc. 3 Computerization will improve the efficiency of health care. Its successful implementation is likely to be directly related to nurse's knowledge, attitude and skills on computer. Therefore, it is necessary to asses these factors and study the relationships among them. Universities are investing huge resources in online education. 4

The use of online technologies in higher education is a relatively recent, yet a rapidly growing. Despite the importance of online technologies to universities, the rationales and justifications for their use are largely either 
unstarted or taken-for-granted by university managers. 5

Globalisation in nursing education is challenges now a day because of the nurse's demand in the international labour market. Therefore, our nursing education should be quality so that our product could demonstrable internationally to provide confidence in a nation's education in the global market.

The general objective of the study was to assess the knowledge, skills and attitude regarding computer education among the Bachelor of Nursing (BN) 1st year students of Nepal.

\section{Methods}

The Research design is based on descriptive method. The study was conducted on 2nd-14th August, 2009. The population of the study were all the nurses who were studying 1st year BN courses in three different institutes. In the research study, non-probability purposive sampling technique was adopted. All together there were $128 \mathrm{BN} 1 \mathrm{st}$ year students from three campuses but only 108 students were participated in the study. A self-administered, structured questionnaire, 4-6 range Likert scale and open ended questionnaire were developed. Data were collected through self-report method by providing a prepared questionnaire for individual respondent. The self administered questionnaire had been divided into six parts:

Part I : Personal biography of respondent

Part II : Basicknowledge about computer

Part III : Uses of computer

Part IV : Attitude towards computer

Part V : Others, different aspects

Part VI : Opinions/recommendations

\section{Validity and reliability}

In order to maintain content validity, the respective questionnaire was prepared by reviewing related literature, and the researcher's personal experience. Questionnaire was pre-tested in Nepal Institute of Health Sciences, Boudha and feedback from the pre-test was incorporated into the final questionnaire design to improve validity and reliability.

\section{Ethical issues}

The investigator formally requested and obtained officially written permission to carry out the study from the three nursing campuses. Verbal consents were taken from each student and confidentiality in terms of information disclosed and identity of students was ensured. The investigator briefed about the objectives of the study, followed by half hour duration of time to fill up the questionnaire.

\section{Data Management and Analysis}

The collected data were entered into SPSS version 11.5. Descriptive statistics were calculated.

\section{Result}

Most of the respondents (44.4\%) belong to Central development region. Likewise, most of the respondents (45.3\%) were found to be $20-24$ years. Similarly, majority of the respondents $(60.2 \%)$ were unmarried out of total 108 . Likewise, majority $(59.3 \%)$ of the respondents had received training in computer. 
Table 1: Personal biography of respondents

$\begin{array}{lcc}\text { S.N. } \quad \text { Demographic characteristics } & \text { Number } & \text { Percent } \\ \text { 1. Permanent address of respondents } & & \\ \text { a. Far western development region } & 4 & 3.70 \\ \text { b. Mid western development region } & 11 & 10.18 \\ \text { c. Western development region } & 28 & 25.92 \\ \text { d. Central development region } & 48 & 44.44 \\ \text { e. } \quad \text { Eastern development region } & 17 & 15.74 \\ \text { 2. Age of the respondents (years) } & & \\ \text { a. } \quad 15-19 & 2 & 1.85 \\ \text { b. } \quad 20-24 & 49 & 45.37 \\ \text { c. } \quad 25-29 & 43 & 39.81 \\ \text { d. } \quad 30-34 & 5 & 4.62 \\ \text { e. } \quad 35-39 & 1 & 0.92 \\ \text { f. Above 40 } & 2 & 1.85 \\ \text { 3. Marital status } & & \\ \text { a. Married } \quad 43 & 39.81 \\ \text { b. Unmarried } & 65 & 60.2 \\ \text { 4. Received training in computer } & & \\ \text { a. Yes } & 64 & 59.3 \\ \text { b. No } & 44 & 40.7\end{array}$

Majority of the respondents $33.3 \%$ respondents had average knowledge on E-mail and Internet..

Table2: Basic Knowledge about Computer

Basic Knowledge About Computer

\begin{tabular}{lllllllll} 
S.N. & Program & Excellent & Good & Average & Fair & Poor & None & Total \\
\hline 1. & MS Word & 17 & 27.7 & 17 & 16 & 10.6 & 11.7 & 100 \\
2. & Power Point & 8.8 & 9.9 & $\mathbf{2 8 . 6}$ & 25.3 & 6.5 & 20.9 & 100 \\
3. & MS Excel & 8.3 & 6.3 & $\mathbf{3 0 . 2}$ & $\mathbf{3 0 . 2}$ & 8.3 & 16.7 & 100 \\
4. & MS Dos & 2.8 & 16.7 & $\mathbf{3 0 . 6}$ & 15.3 & 20.8 & 13.8 & 100 \\
5. & Email / Internet & 23.8 & $\mathbf{3 2 . 4}$ & $\mathbf{3 3 . 3}$ & 7.6 & 0 & 2.9 & 100 \\
6. & Adobe Photoshop & 3.3 & 14.3 & 9.9 & 6.6 & 26.4 & $\mathbf{3 9 . 5}$ & 100 \\
& Operating System & 7 & 18.6 & 12.8 & 10.5 & 22.1 & $\mathbf{2 9 . 1}$ & 100 \\
7. & (Window, Vista, & & & & & & & 100 \\
& Linux) & & & & & & & \\
8. & Installing Software & 6.7 & 5.6 & 17.8 & 8.9 & $\mathbf{3 7 . 7}$ & 23.3 & 100 \\
9. & Virus \& Antivirus & 6.3 & 10.4 & 11.5 & 9.4 & $\mathbf{3 4 . 3}$ & 28.1 & 100 \\
10. & Problems with & 0 & 8.3 & 11.5 & 6.3 & $\mathbf{4 2 . 6}$ & 31.3 & 100
\end{tabular}


Majority of the respondents (54.9\%) use computer for medical information and (48.2\%) occasionally use for games.

Table 3: Use of Computer

\begin{tabular}{|c|l|c|c|c|c|c|}
\hline S.N. & \multicolumn{1}{|c|}{ Purpose of use } & Use all time & $\begin{array}{c}\text { Use } \\
\text { occasionally }\end{array}$ & Use rarely & Never use & Total \\
\hline 1. & Data Base & 6.9 & $\mathbf{3 7 . 9}$ & 35.6 & 19.6 & 100 \\
\hline 2. & Email / Internet & 41.2 & $\mathbf{4 7 . 1}$ & 8.8 & 2.9 & 100 \\
\hline 3. & Chat & 28.1 & $\mathbf{4 0 . 6}$ & 28.1 & 3.2 & 100 \\
\hline 4. & Medical News & 7.3 & $\mathbf{5 4 . 9}$ & 26.8 & 11.0 & 100 \\
\hline 5. & Research & 19.0 & $\mathbf{3 8 . 1}$ & 14.3 & 28.6 & 100 \\
\hline 6. & Listening Music & 33.3 & $\mathbf{4 4 . 4}$ & 17.2 & 5.1 & 100 \\
\hline 7. & News update & 20 & $\mathbf{4 2 . 2}$ & 16.7 & 21.1 & 100 \\
\hline 8. & Games & 18.8 & $\mathbf{4 8 . 2}$ & 29.4 & 3.6 & 100 \\
\hline
\end{tabular}

Table 4: Attitude towards computer

\begin{tabular}{|c|c|c|c|c|c|c|c|}
\hline S.N. & Question & $\begin{array}{l}\text { Strongly } \\
\text { Agree }\end{array}$ & Agree & Undecided & Disagree & $\begin{array}{l}\text { Strongly } \\
\text { Disagree }\end{array}$ & Total \\
\hline 1. & $\begin{array}{l}\text { Without computer, world } \\
\text { would be better }\end{array}$ & 6.1 & 2 & 3 & 19.2 & 69.7 & 100 \\
\hline 2. & $\begin{array}{l}\text { Computer can be used } \\
\text { more at home }\end{array}$ & 53.7 & 38 & 0 & 2.8 & 5.6 & 100 \\
\hline 3. & $\begin{array}{l}\text { Using computer in evening } \\
\text { is better than instead of } \\
\text { going out with friends }\end{array}$ & 20 & 36 & 26.7 & 17.1 & 0 & 100 \\
\hline 4. & $\begin{array}{l}\text { Working with computer is } \\
\text { enjoyable }\end{array}$ & 28.6 & 68.6 & 0 & 2.9 & 0 & 100 \\
\hline 5. & $\begin{array}{l}\text { Computer is necessary to } \\
\text { enhance the knowledge }\end{array}$ & 60.2 & 37 & 0 & 0 & 2.8 & 100 \\
\hline 6. & $\begin{array}{l}\text { Computer develops self- } \\
\text { confidence in working }\end{array}$ & 46.3 & 39.8 & 8.3 & 5.6 & 0 & 100 \\
\hline 7. & $\begin{array}{l}\text { Computer creates a lot of } \\
\text { problem during the time } \\
\text { of use }\end{array}$ & 6.5 & 53.7 & 17.6 & 19.4 & 2.8 & 100 \\
\hline 8. & $\begin{array}{l}\text { Cost of computer is very } \\
\text { expensive }\end{array}$ & 4.8 & 40 & 20 & 35.2 & 0 & 100 \\
\hline 9. & $\begin{array}{l}\text { Sometimes computer gives } \\
\text { false information }\end{array}$ & 12.4 & 41 & 19 & 24.8 & 2.9 & 100 \\
\hline 10. & $\begin{array}{l}\text { Computer makes people } \\
\text { lazy }\end{array}$ & 9.5 & 28.6 & 11.4 & 36.2 & 14.3 & 100 \\
\hline
\end{tabular}


Majority of the respondents (86.1\%) had computer at their home. Similarly, majority of the respondents (52.7\%) thought that life becomes hard, blind, boring, backward and dull without computer. Likewise, majority of the respondents $(95.3 \%)$ used computer to get more information/knowledge/news about world in the short period of time. Majority of the respondents (37\%) used the computer for Internet/E-mail and chatting.

Table 5: Other additional questions
S.N.
Variables
Number Percent

1. Do you have computer at your home?

a. Yes

93

86.1

2. What do you think life without computer?

a. Hard, blind, boring, backward and dull, valueless $\quad 57 \quad 52.7$

b. Creates various problems in life and further study. $\quad 31 \quad 28.7$

Life without computer is a man going in war without sords, curry without

c. $\quad$ ingredients, tea without sugar, moon without light, fish without water as well $\quad 9 \quad 8.3$ as a person without eyes and animal without tail.

d. Difficult to get data and information when needed.

$6 \quad 5.5$

3. How has computer changed the efficiency of your career work?

Getting more information/knowledge/news about world in the short period

a. of time.

b. Makes our work easy, accessible, faster and reliable.

103

95.3

c. Develop knowledge, skills and attitude.

$44 \quad 40.7$

$11 \quad 10.1$

4. What programme do you often use in your computer?
a. Internet/E-mail and chatting
40
37
b. Programming
$23 \quad 21.2$
c. Typing, saving, file setting, data recording and printing.
$20 \quad 18.5$
d. Webpage
$17 \quad 15.7$
e. Ms-Word

$12 \quad 11.1$
f. Designing

$10 \quad 9.2$
g. Playing games
$10 \quad 9.2$
h. Listening music and watching movie
$7 \quad 6.4$
i. Global search
$6 \quad 5.5$
j. Ms-Excel
$6 \quad 5.5$

Majority of the respondents $(40.7 \%)$ gave the opinions that the computer would be very useful in nursing education and research in future. 
Table 6: Opinions about application of computer in nursing education in future.

\begin{tabular}{clc} 
S. $\mathbf{N}$. & Opinions about application of computer in nursing education in future. & $\begin{array}{c}\text { No. of } \\
\text { respondents }\end{array}$ \\
\hline 1. & Very useful in nursing education and research & $44(40.7)$ \\
2. & It helps to make up-to-date knowledge and skills. & $23(21.2)$ \\
3. & It is very important and new technology. & $19(17.5)$ \\
4. & Add computer education in Bachelor of Nursing and Proficiency Certificate & $13(12)$
\end{tabular}

\section{Discussion}

New information relevant to nursing practice doubles every 5 years, indicating a rapid rise in nursing research. Nevertheless the percentage of nursing staff that use data generated by research is rather small, 6 and, even in developed countries, there is a slow emergence of nursing informatics in nursing curricula.7

In the study in Portugal, it was found that nurses' knowledge on information technology was basic and intermediary and acquired mostly by self-teaching.

It is possible that the above findings reflect the current status in IT diffusion in education in Greece, which is still in infancy, in comparison with the most Western European countries. 8

A study in Sweden found that nursing students who used computers at home rated themselves as more skilled in using computers.9 In Sweden, 66\% of nursing students had access to internet at home, while in New Zealand this percentage reached to $93 \% .9$

Computers are often imposed without adequate preparation and support for the nurses involved. A systematic effort has to be taken in order new technology to be incorporated in nursing studies.10 Web-based learning can be an effective mode of delivery for nursing education.11This would lead to the successful implementation of new learning options, including flexible learning.

Educators have to know if today's nursing students are competent of transferring their current technology skills to nursing/hospital information systems in Clinical settings or computer technologies used in institution. The introductory course to nursing/healthcare informatics which is already included in curricula of the nursing studies in Greece does not considered to be adequate for the students regarding their competence in technology skills. Thus, introducing a set of technology courses throughout the nursing program of study, with the goal of enhanced preparing students for this era of rapidly altering technological advancements, is vital. This educational imperative will assist future nurses to exhibit informatics competencies at the point-of care and assist interested future nurse educators to use appropriate ubiquitous e-learning tools in classroom settings.

Most of the respondents $(86.1 \%)$ has computer in their home which is also supported by Deltsidou et al. According to them, half of the students had a PC of their own. Not only this, they also supported the study that $33.3 \%$ respondents have average knowledge on E-mail and Internet. According to them, internet access was limited to $30 \% .12$

Majority of the nursing students scored in average knowledge in PowerPoint, Ms-Excel, Ms-Dos and Email/ Internet which is also supported by Russell and Alpay, that a substantial number of nurses have not yet acquired adequate knowledge of information technology. 13

According to the study of Raja et. al., showed that majority of the respondents $75 \%$ had good computer knowledge. $100 \%$ of nurses had positive attitudes towards computer utilization. $50.8 \%$ and $30.8 \%$ had average and fair computer skills respectively. 14

Getty et. al. reported that nurses both non users and users had favourable attitudes, this supported the present study. 15 Liu et. al, revealed that nurse's computer skills were at moderate levels which is similar to the study. 16

\section{Conclusion}

Based on the result of the study, it is indicated that most of the students are either average or below averages on using computer for different purposes. The result indicates that majority of the students use computer occasionally for different purpose. After analysing the data, almost all respondents shows positive attitude regarding computer. Till now they are unable to introduce computer as a major tool for academic purpose and other activities. So computer course should be added in the BN 1st year curriculum. 


\section{Acknowledgements}

I would like to thank Prof. Dr. PradeepVaidya, Department Head of General Surgery, TUTH and Department of Information Technology, TU, IOM for inspiring me to prepare the article. Similarly, I would like to thank Prof. Dr. Shiva Ram Dhakal, Visiting Professor for IGNOU, India for guiding me. I would also like to thank the Campus Chief of NC, ACAS and SHCCCL and the students of those campuses for giving me opportunity and their help as well. Finally, I would also like to thank Ms. Amrita Chaulagain for assisting in journal writing through computer basis.

\section{References}

1. Ehrmann SC. The Flashlight Project: Tools for Monitoring the Progress of our Hopes and Fears about Technology in Education. The Technology Source. (1998 July). Available online at http:// ts.mivu.org/default.asp?show=article $\& \mathrm{id}=1034$.

2. Joch A. IT at a crossroads. H \& HN/AHA. 2008; $82(2): 45-6$

3. Pocklington D, Baron J. Symposium on computer in nursing: The nursing clinics of North America. Philadelphia: W.B. Saunders Company; 1985; 20 (3): 557-567.

4. Chedake MB. Use of computers in nursing. A good innovation. The nursing journal of India. 1999; LXXXX(12): 226-267.

5. Ehrmann SC. Access and/or Quality?Redefining Choices in the Third Revolution. Available:http:// www.tltgroup.org/resources/or\%20quality. htm14/5/02]. (1999).

6. Carlock D, Anderson J. Teaching and assessing the database searching skills of student nurses. Nurse Educ. 2007;32 (6): 251-5

7. Hardly JL, Lindqvist R, Kristofferzon ML, Dahlberg O. The current status of nursing informatics in dergraduate nursing programs: Comparative case studies between Sweden and Australia. Stud Health Technol Inform. 1997;46:132-6

8. Internet World Stats Internet [homepage on the Internet]. Usage in Europe Internet User Statistics $\&$ Population for 52 European countries and regions. Available from: http://www.internetworldstats.com/ stats4.htm.

9. Honey M. Flexible learning for postgraduate nurses: A basis for planning. Nurse Educ Today. 2004;24(4):319-325
10. Jacso P. Google scholar: The pros and cons. Online Information Review. 2005;29(2):208-214.

11. Nelson R, Meyers L, Rizzolo MA, Rutar P, Proto $\mathrm{MB}$, Newbold S. The evolution of educational information systems and nurse faculty roles NursEducPerspect. 2006;27(5):247-53

12. Deltsidou A, Voltyraki EG, Mastrogiannis D, Noula M. Undergraduate nursing students' computer skills assessment: A study in Greece. Health Science Journal. 2010;4(3):184

13. Russell A, Alpay L. Practice nurses' training in information technology: Report on an empirical investigation. Health Informatics Journal, 2000; 6: 142-146.

14. Raja EJ, Mahal R, Masih VB. An Exploratory Study to Access the Computer Knowledge, Attitude and Skill Among Nurses in Health Care Setting of a Selected Hospital. India: (Feb, 2004); 8(1)

15. Getty M, Ryan AA, Ekins ML. A Comparative study of the attitudes of users and non-users towards computerized care planning. Journal of clinical nursing. 1999; (4): 431-439.

16. Liu JE, Pothiban LL, Khamphosiri T. Computer Knowledge, attitudes and skills of nurses in peoples Hospital of Beijing Medical University. Computers in Nursing. 2000; 18(4): 197-206. 